\title{
Waste Management Practices in Selected Poultry Farms and its Effect on the Environment and Human Health in Makurdi, Nigeria
}

\author{
*H.O. Abah, A.U. Nwankwo and C.M. Orgem
}

\begin{abstract}
Department of Veterinary Medicine, College of Veterinary Medicine, University of Agriculture Makurdi, Benue State, Nigeria
\end{abstract} E-mail: helenabah505@gmail.com

\begin{abstract}
The poultry industry produces large amounts of waste that include solid waste and wastewater. These waste if not properly disposed can be risky to the environment and humans through the spread of diseases and pollution of soil and groundwater. The investigation to determine poultry waste management practices and its effect on the environment and human health was carried out in Makurdi. Benue State. The study was conducted from October to December 2017. A structured questionnaire was administered to 20 randomly selected poultry farmers and 20 neighbours in the study area by one on one interview and observation of the environment. Data collected from the questionnaires were analysed using descriptive statistics. The major poultry waste generated by the farms was faecal waste (50\%) with about $50 \%$ of the respondents getting 25 bags or more of waste after clearance of poultry houses. There was no significant difference $(P=0.056)$ between the flock size and the number of bags gotten from clearance of the litter. About (40\%) of the farms sell their poultry waste immediately after clearing their farms while 30\% applied theirs directly to nearby farm lands. The challenges in disposing of poultry waste were shortage of labour (45\%) and lack of dumping sites (25\%). The major complaint about poultry farms by neighbours living around the farms was bad odour (60\%). It was observed that improper handling of poultry production waste from start to finish could lead to environmental and health hazards with $60 \%$ of the respondents reported being sick with signs of respiratory problems and $40 \%$ had digestive problems. Eighty-five (85\%) percent of the farmers indicated that improper disposal of litter causes surface water contamination while all (100\%) the farmers agreed that poultry waste causes air pollution. It was concluded that waste management by poultry farmers in the study area was inefficient. There is a need for further studies to assess the magnitude of the risk posed by poor poultry waste management practices to the environment, livestock and human health.
\end{abstract}

Keywords - Disposal, poultry waste, litter, poultry farms, Makurdi.

\section{INTRODUCTION}

Worldwide, the poultry industry is growing rapidly and contributes towards addressing key national development goals, as well as improving the standard of living of people through poverty alleviation and creating employment opportunities(Agblevoret al., 2010). Poultry farming is one of the largest and fast growing agricultural businesses worldwide, this is due to its economic and health benefits(Adeoyeet al., 2004). There is high demand for poultry products in form of meat and eggs which makes poultry business to be lucrative with high source of income(Akilu, 2008).Waste is defined as anything that is no longer useful and needs to be disposed of. The poultry industry produces large amounts of waste that include solid waste and wastewater. The solid waste consists of bedding material, excreta (manure), feed, feathers, hatchery waste, shells, sludge, abattoir waste (offals, blood, feathers and condemned carcasses) and mortality(Moreki and Chiripasi, 2011). The wastewater results from washing and disinfection of chicken houses and abattoirs (Moreki and Chiripasi, 2011). Reports from Dong and Tollner(2003) stated that poultry densities on farms continue to increase and have caused manure related problems which are water, air and land pollution. Livestock manure can be either a valuable resource or an environmental pollutant. Generally, manure refers to faeces and urine produced by animals, and it contains organic matter and nutrients, that has fertilizer value when applied on the land and used by crops. The proper handling and management of manure can augment or replace purchased commercial fertilizers(Tao and Mancl, 2008). On the other hand, poultry litter is a mixture of poultry droppings and bedding materials, such as wood shavings and rice or peanut hulls). In Nigeria, like any developing nation, there is a rapid expansion of small and medium scale poultry farms with the attendant effect of 
huge waste generation. The magnitude of this generated poultry waste has given rise to improper disposal which include over application to land, improper timing of application thereby creating pollution problem to soil water and air environment(Adewumiet al., 2011).There are several ways of disposing poultry waste which include burial, rendering, incineration, compositing, feed for livestock, fertilizer or source of energy.(Moreki and Kealkitse, 2013). Other waste disposal methods include conversion of poultry waste to energy and use of poultry waste for treatment of heavy metal contaminated water(Moreki and Chiripasi, 2011). Modern management methods for poultry waste like re-feeding to animals, green disposal, gasification and biogas production have not gained prominence in Nigeria probably due to level of awareness, lack of strict regulation from government in respect of poultry waste disposal and care-free attitude of the farm owners (Adeoye, et al., 2004). It is still a common site in Nigeria to see huge deposit of poultry waste around the farm, flushing of the waste into water courses through open canals from farms are also common sites (Ojoloet al., 2007). These methods are not only unsightly, it also creates a lot of environmental nuisance and surface and groundwater pollution(Akinbile, 2012). This work was conducted to identify the waste management methods used in poultry farms in Makurdi metropolis, Benue State, the problems encountered during waste disposal and its as sociated effects on the environment and human health.

\section{MATERIALS AND METHODS}

\subsection{Study area}

The study was conducted in Makurdi Local Government Area of Benue State. Makurdi is the capital of Benue state, Nigeria. The city is located in North Central Nigeria along the Benue river and lies on latitude $07^{\circ} 43^{\prime} 50$ North and Longitude $08^{\circ} 32^{\prime} 10$ East. The climate of the state is characterized by an average annual minimum and maximum temperature of $22.43^{\circ} \mathrm{C}$ and $33.41^{\circ} \mathrm{C}$ respectively and the annual rainfall ranges from 1270-1397 mm(Olaniran and Sumner, 2006). The local government has 11 council wards with an estimated population of 500,797 people(NPC, 2010).

\subsection{Methods of data collection}

For this study, twenty (20) registered poultry farms and 20 neighbours living around the poultry houses were randomly selected.A structured questionnaire was designed to collect information from poultry farmers about their manure/litter management procedures and neighbours about the effect of poultry waste on the environment and human health. The questionnaire was designed to adequately capture relevant information such as type of management system, kind of www.ijeab.com disposal methods used to remove manure/litter, constraints or major challenges of waste disposal in poultry farms, symptoms of sickness experienced by neighbours etc. Some data were collected through one on one oral interview with the farm owners and household heads using the questionnaire. This study was carried out during the dry season from October to December 2017. Forty (40) questionnaires were administered, 20 to poultry farms and 20 to neighbours in North Bank 1, North Bank 2, Agan, Wadata, Modern Market, Fiidii and Waimalayo council wards of Makurdi, Benue State.

\subsection{Data analysis}

The data obtained from the questionnaires were analyzed using descriptive statistics using SPSS (version 20). The frequencies, percentages and chi square values where calculated. Results were presented in charts and tables. Value of $\mathrm{P} \leq 0.05$ was considered significant.

\section{RESULTS AND DISCUSSION}

The results from this study showed that most poultry farmers preferred to rear broilers $(50 \%)$ (Table 1). Majority of them had broilers in their farms at the time of sampling. This might be due to the fact that broiler production is more profitable than layer production in this part of the country (Laseindeet al., 2005). Also, due to the high temperature in the study area, most poultry farmers would prefer keeping birds for a short period of time before selling(Amos, 2006).Most (80\%) of the poultry farms visited kept birds in deep litter system and all $(100 \%)$ of the poultry houses had concrete floors. The use of the deep litter system by most poultry farmers in Makurdi may be attributed to its cost effectiveness in terms of construction and thereby making it easier to manage(Musa andSaidu, 2012). Concrete floors are damp proof thereby making it easier to manage litter(Moore et al., 2004).About $15 \%$ of the poultry farmers used saw dust as their bedding material, $40 \%$ used wood shavings while $5 \%$ do not use any bedding materials (Table 1).The type of bedding material used by farmers depends on locality and availability. The fact that wood shavings and saw dust was mostly used by the poultry farmers in the study area showed that it is relatively cheap and readily available(Ekenma,2015).Some other workers reported that saw dust was the most popular litter material used in most nations for poultry production(Charles, 2005). Sixty-five $(65 \%)$ of the farms sampled change their litter once a week, $10 \%$ change theirs every day and every month respectively with $15 \%$ changing theirs every 6 months (Table 1). Most $(90 \%)$ of the respondents clear out all the litter and sweep the floor of the poultry house before replacing with new litter material while $10 \%$ remove only the topmost caked parts of the litter and replace with new one without

Page | 122 
sweeping the floors (Table 1).The type of bird also affects the frequency with which the litter materials are changed because daily production of litter by layers has been estimated to be higher than that of broilers (Tao andMancl, 2008). Also, the frequency in the change of poultry litter may also be due to poor quality structures, poor management practices and frequent weather variation(Sa'idu, et al., 2008). Most of the farms clear out all the litter and sweep the floor of the poultry houses i.e. total clean out before replacing with new litter, while others remove only the topmost caked parts of the litter without sweeping the floors. Only $10 \%$ of the farmers said they have heard of litter treatment before disposal while $90 \%$ have not heard of treatment of manure prior to disposal. This indicates that poultry waste treatment is not a familiar practice in Makurdi. Ninety (90\%) percent of the farmers reported they got no visits from the state sanitation bodies while $10 \%$ acknowledged visitation from sanitation bodies which was sometimes once a year.The method of litter disposal by poultry farmers in the study area includes selling it off immediately to farmers (40\%), storing and selling later (30\%) and application as manure to nearby farm lands $(30 \%)$. This is similar to the work done by Embury(2004) in Port Harcourt Nigeria where most of the poultry farmers sell off their bags of litter immediately after collection from the poultry houses with other farmers storing and applying to nearby farmlands. The majority of the farmers from these results have good market for their poultry waste hence a good disposal system because a good number of them sell off their poultry waste immediately. Whether poultry waste is sold off, stored or applied to farm land immediately, a greater portion of poultry waste end up in farm lands(Shah et al., 2009). All (100\%) the farmers agreed that improper poultry waste disposal could be hazardous to human health with $60 \%$ of the respondents indicating respiratory problems as the major effect on human health while $40 \%$ stated digestive problems (Table 1).Symptoms of conjunctivitis and sneezing were reported by farmers and neighbours living around the poultry farms. This could be related to the ammonia produced from the poultry waste(Akanni and Benson, 2014).

Table.1: The frequency of the different variables used in the study.

\begin{tabular}{|c|c|c|}
\hline Variables & Number of farms & Percentage $(\%)$ \\
\hline \multicolumn{3}{|l|}{ Type of birds } \\
\hline Layers & 1 & 5.0 \\
\hline Broilers & 10 & 50.0 \\
\hline Layers and broilers & 9 & 45 \\
\hline Total & 20 & 100.0 \\
\hline \multicolumn{3}{|l|}{ Management system } \\
\hline Battery cage & 1 & 5.0 \\
\hline Deep litter & 16 & 80.0 \\
\hline Battery cage and deep litter & 3 & 15.0 \\
\hline Total & 20 & 100.0 \\
\hline \multicolumn{3}{|l|}{ Type of floor } \\
\hline Concrete floor & 20 & 100 \\
\hline Un cemented floor & 0 & 0 \\
\hline Total & 20 & 100 \\
\hline \multicolumn{3}{|l|}{ Type of litter } \\
\hline Saw dust & 3 & 15.0 \\
\hline Wood shaving & 8 & 40.0 \\
\hline Both & 8 & 40.0 \\
\hline Others & 1 & 5.0 \\
\hline Total & 20 & 100.0 \\
\hline \multicolumn{3}{|l|}{ Method of litter removal } \\
\hline Clear all and sweep floor before replacing & 18 & 90.0 \\
\hline Remove only topmost litter & 2 & 10.0 \\
\hline Total & 20 & 100.0 \\
\hline \multicolumn{3}{|l|}{ Frequency of litter change } \\
\hline Every day & 2 & 10.0 \\
\hline
\end{tabular}


Once a week

Every month

Every 6 months

Total

Poultry waste disposal method

Sell off immediately

Store and sell later

Apply to farmland

Total

Effects of poultry waste on human

health

Respiratory problems

Digestive problems

Total

13

2

3

20

$8 \quad 40.0$

$6 \quad 30.0$

$6 \quad 30.0$

$20 \quad 100.0$
65.0

10.0

15.0

100.0

60.0

40.0

100.0

The flock size of the farms ranged from 100 - 5000 birds (Table 2). Result showed that most of the poultry waste generated by these farms was faecal waste, others include staled eggs, dead birds and feathers (Table 3).

Table.2: Flock size of selected poultry farms in Makurdi metropolis, Benue State.

\begin{tabular}{lll}
\hline Flock size & Number of farms & Percentage $(\%)$ \\
\hline $100-500$ & 4 & 20.0 \\
$500-1000$ & 10 & 50.0 \\
$1000-1500$ & 1 & 5.0 \\
$1500-2000$ & 2 & 10.0 \\
$2000-5000$ & 3 & 15.0 \\
Total & $\mathbf{2 0}$ & $\mathbf{1 0 0 . 0}$ \\
\hline
\end{tabular}

Table.3: Type of poultry waste generated by farms in Makurdi metropolis, Benue State

\begin{tabular}{lll}
\hline Poultry waste & Number of farms & Percentage (\%) \\
\hline Faecal waste & 10 & 50.0 \\
Staled egg & 3 & 15.0 \\
Dead birds & 3 & 15.0 \\
Feathers & 2 & 10.0 \\
Others & 2 & 10.0 \\
Total & $\mathbf{2 0}$ & $\mathbf{1 0 0 . 0}$ \\
\hline
\end{tabular}

The quantity of waste generated by the farms showed that $90 \%$ of the farmers generate more than $400 \mathrm{~kg}$ of poultry waste each time they cleared out their poultry farms, $5 \%$ get $200-400 \mathrm{~kg}$ and another $5 \%$ get less than $200 \mathrm{~kg}$. About $50 \%$ of the respondents get 25 or more bags of waste after clearance, $20 \%$ get between 11-15 bags (Table 4). There was no association between the flock size and the number of bags gotten from clearance of the litter $(\mathrm{P}=0.056)$. The number of bags of litter gotten by individual farmers in this study depended on several factors such as type of feed, quantity of feeds consumed by birds, type of birds, feed conversion rate, stocking density and other managerial factors(Ekenma,2015).Also, the frequency at which the poultry houses are cleaned can affect the numbers of bags gotten from each clearance (Agblevoret al., 2010). The longer the clearance interval, the higher the quantity of poultry wastes gotten. According to $\operatorname{FAO}(2012)$,it is necessary a poultry farmer knows the quantity of waste produced by his birds because it helps in planning or designing an effective waste management program. 
Table.4: Number of bags after clearance of poultry houses in Makurdi, Benue State

\begin{tabular}{lll}
\hline Number of bag & Number of farms & Percentage $(\boldsymbol{\%})$ \\
\hline $1-5$ & 2 & 10.0 \\
$6-10$ & 3 & 15.0 \\
$11-15$ & 4 & 20.0 \\
$16-20$ & 1 & 5.0 \\
21 and above & 10 & 50.0 \\
Total & $\mathbf{2 0}$ & $\mathbf{1 0 0 . 0}$ \\
\hline
\end{tabular}

The major complaint by the neighbours living around the poultry farms was the odour $(60 \%)$ that emanates from the poultry houses while $25 \%$ complained about the noise from the birds (Table 5). Most of the respondents (45\%) reported shortage of labour as their major constraint of waste disposal with $25 \%$ complaining of no dumping site, $20 \%$ reported no market to sell and $10 \%$ complained about transportation cost (table 6). There was a significant level of association between waste disposal methods and the constraints of waste disposal in the farms sampled $(\mathrm{P}=0.000)$.

Table.5: Complaints of neighbours about poultry farms in Makurdi, Beune State

\begin{tabular}{lll}
\hline Complaints & Number of farms & Percentage (\%) \\
\hline Foul odour & 12 & 60 \\
Noise from birds & 5 & 25 \\
Pollution of nearby waters & 3 & 15 \\
Total & $\mathbf{2 0}$ & $\mathbf{1 0 0 . 0}$ \\
\hline
\end{tabular}

Table.6: Constraints of poultry waste disposal by poultry farms in Makurdi, Benue State

\begin{tabular}{lll}
\hline Constraints & Number of farms & Percentage (\%) \\
\hline No dumping site & 5 & 25.0 \\
No market to sell manure & 4 & 20.0 \\
Transportation cost & 2 & 10.0 \\
Shortage of labour & 9 & 45.0 \\
Total & $\mathbf{2 0}$ & $\mathbf{1 0 0 . 0}$ \\
\hline
\end{tabular}

Poultry facilities are a source of odour and attract flies, rodents and other pests that create local nuis ances and carry diseases(Moore,et al., 2004). Odour emissions from poultry farms adversely affect the life of people living in the vicinity and from this study, residents complained of the bad odour coming from the farms. This has led to most of the residents complaining and confronting the poultry farmers. Odour associated with poultry operations comes from fresh and decomposing waste products such as feaces, carcasses, feathers and bedding/ litter(Ferke et al., 2002; Kolominskas et al., 2002).

Results showed that most of the farmers were aware of the effect of improper poultry waste disposal on human health and the environment. Reports from other researchers
(Akanni and Benson, 2014, Moore et al., 2004) also revealed that activities in livestock production facilities cause environmental problems such as odour nuisance and land pollution resulting from improperly discharged manure. Forty percent of the respondents indicated that creation of proper dumping sites was the best strategy for waste management while $35 \%$ were of the opinion to encourage farmers to use the waste material on farmland (Table 7). Eighty-five (85\%) percent of the farmers also indicated that improper disposal of litter causes surface water contamination while all $(100 \%)$ the farmers agreed that poultry waste causes air pollution.Also, $45 \%$ of the respondents knew that improper disposal of litter material had an effect on the soil (Table 8). 
Table.7: Strategies for proper waste management in Makurdi, Benue State

\begin{tabular}{lll}
\hline Strategies & Number of farms & Percentage (\%) \\
\hline $\begin{array}{l}\text { Encourage famers to use poultry waste } \\
\text { on farm land }\end{array}$ & 7 & 35.0 \\
$\begin{array}{l}\text { Create proper dumping site } \\
\begin{array}{l}\text { Educate farmers on other ways to } \\
\text { utilize poultry waste }\end{array}\end{array}$ & 8 & 40.0 \\
Total & $\mathbf{2 0}$ & 25.0 \\
\end{tabular}

Table.8: Knowledge and awareness of poultry farmers on the effect of poultry waste on the environment in Makurdi, Benue State (no. offarms $=20$ )

\begin{tabular}{llll}
\hline Awareness & & Number of farms & Percentage (\%) \\
\hline $\begin{array}{l}\text { Contamination of ground } \\
\text { water }\end{array}$ & Yes & 11 & 55 \\
& No & 9 & 45 \\
Contamination of surface & Yes & 17 & 85 \\
water & & & \\
& No & 3 & 15 \\
Air pollution & Yes & 20 & 100 \\
& No & 0 & 0 \\
Contamination of soil & Yes & 9 & 45 \\
& No & 11 & 55 \\
\hline
\end{tabular}

These results showed that excessive application of poultry manure on farm lands may lead to undesirable effects on forage crops and animals consuming the forage This could also result to leaching of nitrate into ground water thereby causing water pollution(McGinley et al., 2003).

\section{CONCLUSION AND RECOMMENDATIONS}

This study showed that there is poor management of poultry wastes in Markurdi metropolis, Nigeria. The disposal methods in practice may bear grave implications for the environment, livestock and public health. There should be strict enforcement by supervisory agencies of existing policies aimed at environmental sanitation and the protection of water quality. Alternative methods for the utilization of poultry wastes such as biogas production and conversion to inorganic manure using modern recycling facilities should be considered by stakeholders in the study area.

\section{REFERENCES}

[1] Agblevor F.A.,Beis, S., Kim, S.S., Tarrant R. andMante, N.O. (2010). Biocrude oils from the fast pyrolysis of poultry litter and hardwood. Waste Management, 30: 298-307.

[2] Adeoye, G.O.,ShridarM.K. and Mohammed, O.E. (2004). Poultry waste management for crop production: Nigerian experience. Waste Management and Res. 22:165-172.

[3] Akilu, Y.(2008). Performance monitoring report (2006-2007) Ethiopia, SPS-LMN program

TAES/TAMUS, Addis Ababa.

[4] Moreki, L.C. andChiripasi, S.C. (2011). Poultry waste management in Bostwana: A review. Online J. Animal and Feed Research., 1(6): 285-292.

[5] Dong, X. andTollner, E.W.(2003). Evolution of anammox and denitrification during anaerobic digestion of poultry manure. Bioresource Technology, 86:139-145.

[6] Tao, J. andMancl, K. (2008). Estimating manure production, storage size, and land application area. Fact Sheet Agriculture and Natural Resources AEX715-08, The Ohio State University Extension. ohioline.osu.edu/aexfact/pdf/0715.pdf.

[7] Adewumi, A.A.,Adewumi,I.K. andOlaleye, V.F. (2011). Livestock waste management: Fish wealth solution. African journal of environmental science and technology, 5: 149-154

[8] Moreki J.C. andKealkitse, T. (2013). Poultry waste management practice in selected poultry operation around Gaborone, Bostwana. Int. Journal on microbial applied sci., 2: 240-248. 
[9] Ojolo, S.J.,Oke, S.A.,Animasahun,K. andAdesuyi, B.K. (2007). Utilization of poultry, cow and kitchen wastes for biogas production: A comparative analysis. Iranian J Env Health Sc Eng;4(4):223-228.

[10] Akinbile, C.O.(2012). Environmental impact of landfill on groundwater quality and agricultural soils in Nigeria. Soil and Water Res.;7(1):18-26.

[11] Olaniran, O.J. and Sumner G.N. (2006). A study of climatic variability in Nigeria based on the onset retreat and length of the rainy season, International journal climatology, 9,3:253-269.

[12] National population commission of Nigeria (NPC) (2010). Annual Abstract Statistics Nigeria, 2010 Census local government area page 23.

[13] Laseinde, E.A.O.,ImouduP.B. andOdedele, S.O. (2005). Effect of Cropping Time on Profitability of Broiler Enterprise. In:Onibi, G.E., Agele, S.O. and Adekunle, V.A.J. (eds), 2005. Proceedings of the 1st Annual Conference on Developments in Agriculture and Biological Sciences. 27 April, (2005). School of Agriculture and Agricultural Technology, Federal University of Technology, Akure, Nigeria, pp: 300.

[14] Amos, T.T.(2006). Analysis of backyard poultry production in Ondo state, Nigeria. International journal of poultry science 5(3): 247- 250.

[15] Musa, I.W. andSaidu, L. (2012). Report of disseminated aspergillosis associated with poor litter in Zaria, Nigeria. Vet. Clin. Bull. J. Vet. Teaching Hospital, 2: 17-21.

[16] Moore, P.A., Daniel, T.C., Edwards, D.R.,Sharpley,A.N. and Wood, C.W. (2004). Poultry manure management. J. Env. Qual., 36: 60-75.

[17] Ekenma, K.(2015).Poultry Litter Manure Management Practices in Intensively Managed Poultry Farms in Portharcourt, IOSR Journal of Agriculture and Veterinary Science, 8(3): 53-58.

[18] Charles, E.B.(2005). Litter management for confined Turkeys. Poultry science and technical guide, No. 41, The North Carolina Agr. Ext. Serv. Bull., pp. 3-7.

[19] Sa'idu, L.,Wakawa, A.M., Waziri I.M. and Abdu, P.A. (2008). Stratagies for the control of diseases of rural poultry. Ani. Sci. Asso. Nig., 9: 15-19.

[20] Food and Agriculture Organisation of the United Nations (FAO).(2012). Statistical Yearbook. World Food and Agriculture. Rome. pp.245.

[21] Embury, I.S.(2004). Alternative litter materials for poultry. Poultry Division of Animal Production, NSW Agriculture, http://www.dpi.nsw.gov.au/ littermaterials-for-poultry.pdf.

[22] Shah, S.B., Hutchison, K.J.,Hesterberg, D.L.,Grabow, G.L., Huffman, R.L., Hardy D.H. and Parsons, J.T. www.ijeab.com
(2009). Leaching of nutrients and trace elements from stockpiled turkey litter. J. Environ. Qual. 38: 10531065.

[23] Ferke, P.R., Van Heugten, E., Van Kempen, T.G. and Angel, R. (2002). Nutritional strategies to reduce environmental emissions from non-ruminants. J. Anim. Sci, 80 (E. Suppl. 2): E168-E182.

[24] Kolominskas, C.,Bawden,K. andOrmerod, R. (2002). Strategies to reduce odour emissions from meat chicken farms. In Proceedings 2002. Poultry Information Exchange,pp.27-39 (available at http://www.fsaconsulting.net/pdfs/PIX\%20Odour. PDF).

[25] Akanni, K.A. and Benson, O.B. (2014). Poultry Waste Management Strategies and Environmental Implication on Human Health in Ogun State of Nigeria. Advance in Economic and Business (4) 164171.

[26] McGinley, B.C., Coffey, K.P., Humphry, J.B., Sauer T.J. and Goodwin, H.L. (2003). Mineral content of forages grown on poultry litter-amended soils. Journal of Animal Science 81: 106-111. 